\title{
PENGUATAN KAPASITAS KELEMBAGAAN KELOMPOK PEW UNTUK PENGEMBANGAN EKONOMI LOKAL KOTA YOGYAKARTA
}

\author{
Yuli Kurniyati (yulikurniyati@yahoo.co.id)
}

Fakultas Ekonomi, Universitas Proklamasi 45

\begin{abstract}
The purpose of this study was to analyze institutional capacity the PEW Group Members, and analyzing institutional performance, and formulate strategies and institutional capacity building programs in the PEW Group of local economic development in the city of Yogyakarta. The method used in this study is a qualitative method. Data collection techniques used are: observation , documentation studies, in-depth interviews, and questionnaires. Assessment strategies in the analysis of this problem using the Logical Framework Analysis . Repayment rates in Sub Pringgokusuman PEW group 76 \% ( 25 groups ) are classified as current, $12 \%$ classified as substandard, and there are 4 groups ( $12 \%$ ) were classified as jammed. Judging from the direction of development of the group based on the performance aspects of the organization, administration, financing, production and rooting business, there are 18 ( $54.55 \%$ ) groups were included in the growth category, and 15 ( $45.45 \%$ ) group included in the category of development, while the group in the category are not independent. Formulation of institutional capacity strengthening program group includes : 1 ). Improvement Skills Productive Economic Business Members . 2 ) Strengthening Institutions Norm 3 ). Administrative Arrangement group 3 ). Increased Capital to expand cooperative network.
\end{abstract}

Key words: empowerment, institutional capacity, local economi

\section{PENDAHULUAN}

Program pengembangan ekonomi masyarakat di daerah berintikan pada kebijakan pembangunan yang menggunakan sumberdaya lokal (sumberdaya alam, fisik dan lingkungan), kelembagaan dan sumberdaya sosial ekonomi yang dimiliki daerah. Titik sentral program pengembangan ekonomi masyarakat adalah pada inisiatif daerah (masyarakat dan pemerintah daerah) untuk menggerakkan proses pengembangan ekonomi daerah. Pemikiran dan inisiatif tersebut dituangkan dalam rencana umum yang dapat diterapkan, sesuai dengan permasalahan dan potensi yang 
ideal dalam artian aspiratif, serta rencana pembangunan multisektoral yang disusun oleh pemerintah baik di tingkat regional maupun nasional (Djuli sugiarto, 2006 : 2)

Strategi pemberdayaan masyarakat merupakan upaya pengembangan partisipasi aktif dan meningkatkatkan prakarsa masyarakat dalam menentukan arah tujuan yang akan dicapai dalam lembaga yang dibentuk bersama oleh masyarakat, pengembangan masyarakat merupakan suatu gerakan untuk meningkatkan taraf hidup yang meliputi berbagai kegiatan pembangunan tingkat lokal baik yang dilakukan pemerintah dan nonpemerintah (Adi 2001). Menurut (Sumarjo \& Saharudin 2004) partisipasi masyarakat memegang peranan penting dalam pembangunan masyarakat, karena melalui partisipasi masyarakat dapat diperoleh, Pertama, informasi tentang kondisi, kebutuhan, dan sikap masyarakat. Kedua, masyarakat lebih percaya dan bertanggung jawab bila dilibatkan dalam kegiatan mulai dari perencanan hingga memanfaatkan hasil program. Ketiga, masyarakat beranggapan bahwa keterlibatan mereka dalam pembangunan merupakan hak demokrasi masyarakat itu sendiri.

Penguatan kapasitas lembaga ekonomi lokal melalui pemberdayaan masyarakat, adalah salah satu model peningkatan peran serta masyarakat dalam kegiatan yang dirancang dengan menitikberatkan pada proses pembelajaran dan memberdayakan masyarakat lewat lembaga ekonomi lokal untuk menopang perekonomian masyarakat itu sendiri. Lembaga ekonomi lokal di atas mengandung makna "ikatan sosial" yang dibangun berdasarkan jejaring sosial (social networking) sebagai nilai tambah dari modal sosial (social capital) dengan satu fokus interaksi pada pengembangan masyarakat (Nasdian 2004). Pemerintah Kota Yogyakarta melalui Dinas Perindagkop mulai tahun 2006 telah memberikan penguatan permodalan kepada para pengusaha mikro dan kecil yang tergabung dalam kelompok di 45 Kelurahan se-Kota Yogyakarta melalui kegiatan Pemberdayaan Ekonomi Berbasis Kewilayahan (PEW) sebagaimana diamanatkan Peraturan Walikota Yogyakarta Nomor 71 tahun 2009 tentang Pemberdayaan Ekonomi Berbasis Kewilayahan Melalui Penguatan Modal Usaha Mikro dan Kecil yang disempurnakan dengan Perwal 106 tahun 2009. Pemberdayaan ekonomi berbasis kewilayahan melalui penguatan modal usaha mikro dan kecil yang bersumber dari Anggaran Pendapatan dan Belanja Daerah (APBD) Pemerintah Kota Yogyakarta diharapkan dapat memperkuat usaha mikro dan kecil sehingga mampu tumbuh dan berkembang secara mandiri. Tidak dapat dipungkiri bahwa sampai saat ini kondisi usaha mikro dan kecil di Kota Yogyakarta masih lemah dalam berbagai aspek usaha diantaranya pada aspek permodalan baik dalam hal kemampuan penyediaan modal maupun dalam pengelolaannya. Sampai dengan tahun 2010 tercatat sebanyak 922 kelompok telah mendapatkan penguatan modal dalam bentuk bantuan dana bergulir melalui program PEW ini. (Disperidagkoptan, 2012) 
Pemberdayaan Ekonomi Berbasis Kewilayahan adalah kegiatan yang bertujuan untuk meningkatkan Usaha Mikro dan Kecil di Kelurahan dengan memberikan penguatan permodalan usaha, penguatan modal adalah kegiatan yang ditujukan untuk meningkatkan permodalan usaha mikro dan kecil melalui program bantuan dana bergulir yang dikelola oleh kelompok sebagai pinjaman lunak dana bergulir . Karena program PEW ini sifatnya dana bergulir, maka untuk menghindari kemacetan dalam proses pengembalian diberlakukan sistem tanggung renteng oleh anggota kelompok. Tanggung Renteng adalah kewajiban mengembalikan pinjaman yang harus ditanggung oeh anggota kelompok, manakala salah satu anggota kelompok mengalami masalah dalam proses pengembalian pinjaman. Anggota kelompok ini sekaligus melakukan fungsi kontrol bagi kelestarian dan kesinambungan kelompok. Permasalahan pokok dalam pemberdayaan masyarakat melalui ekonomi lokal adalah rendahnya tingkat keterampilan dan pengetahuan masyarakat, mengakibatkan rendahnya kemampuan masyarakat untuk memperoleh dan memanfaatkan akses sumberdaya yang tersedia. Hambatan lain yang sifnifikan berupa, rendah kemampuan lembaga dan organisasi ekonomi masyarakat dalam mengelola sumberdaya untuk meningkatkan kompetensinya.

Kajian ini penting mengingat potensi usaha mikro dan kecil di Kota Yogyakarta cukup besar dan memberikan kontribusi yang signifikan terhadap perekonomian masyarakat, sehingga perlu untuk didorong dan dikembangkan agar menjadi pelaku ekonomi yang tangguh dan berdaya saing melalui program pemberdayaan ekonomi wilayah (PEW) ini. Dengan memperhatikan masalah yang dihadapi oleh kelembagaan Kelompok PEW dalam pengembangan ekonomi lokal, rumusan masalah dalam penelitian ini adalah :

a. Bagaimana kapasitas kelembagaan dan anggota kelompok Program Pemberdayaan Ekonomi wilayah (PEW) di kota Yogyakarta.

b. Bagaimana kinerja kelompok PEW sebagai lembaga simpan pinjam dalam memberdayakan anggotanya?

c. Bagaimana merumuskan strategi dan program penguatan kapasitas kelembagaan Kelompok PEW dalam pengembangan ekonomi lokal?

Sedangkan tujuan dari penelitian ini adalah sebagai berikut:

a). Menganalisis Kapasitas Kelembagaan dan anggota Kelompok penerima bantuan Program pemberdayaan ekonomi wilayah (PEW) di kota Yogyakarta.

b). Mengevaluasi kinerja kelompok PEW sebagai lembaga simpan pinjam dalam memberdayakan anggotanya.

c) Merumuskan strategi dan program penguatan kapasitas kelembagaan Kelompok PEW dalam pengembangan ekonomi lokal. 


\section{TINJAUAN PUSTAKA}

\section{Pengembangan Ekonomi Lokal}

Menurut Syaukat dan Hendrakusumaatmaja (2004), Pengembangan Ekonomi Lokal (PEL) merupakan kerjasama seluruh komponen masyarakat di suatu daerah (lokal) untuk mencapai pertumbuhan ekonomi berkelanjutan, yang akan meningkatkan kesejahteraan ekonomi dan kualitas hidup seluruh masyarakat di dalam komunitas. PEL diperlukan karena selama ini daerah kabupaten/kota di Indonesia yang memiliki potensi sumber daya alam, manusia dan sosial budaya, belum termanfaatkan secara optimal dalam rangka pemerataan kesejahteraan bagi seluruh masyarakat. Keberhasilan program PEL sangat ditentukan oleh motivasi pemerintah Pusat/Daerah dalam merencanakan, memformulasikan dan mengimplementasikan program-program Otonomi Daerah. Menurut Syaukat dan Hendrakusumaatmaja (2004), Pengembangan ekonomi lokal memberi kesempatan kepada pemerintah lokal, swasta, Lembaga Swadaya Masyarakat (LSM), dan masyarakat lokal untuk secara bersama-sama pro-aktif berusaha untuk memperbaiki dan mengembangkan lingkungan bisnisnya sehingga mereka mampu berkompetisi dengan daerah lainnya, bahkan internasional.

Pengembangan ekonomi lokal difokuskan pada upaya peningkatan daya saing (competitiveness), peningkatan pertumbuhan, dan restribusi pertumbuhan tersebut melalui pembentukan usaha kecil dan menengah (SME: small and medium enterprises) dan penciptaan lapangan kerja (job creation ). Pengembangan Ekonomi Lokal pada lintasan terakhir adalah perbaikan kesejahteraan dan terkait dengan upaya penanggulangan kemiskinan, sedangkan kemiskinan tersebut dicirikan : rendahnya kemampuan masyarakat dalam meningkatkan penguasaan sumber daya lokal (Syaukat dan Hendrakusumaatmaja, 2004). PEL yang mampu menyentuh kelompok lemah tidak dapat diserahkan kepada mekanisme pasar, tetapi memerlukan keberpihakan terhadap kelompok sasaran berupa kebijakan pemerintah daerah dan upaya pemberdayaan sosial ekonomi masyarakat, harus dilakukan dalam kerangka pembangunan yang berkelanjutan yaitu pemanfaatan sumber daya alam dengan memperhatikan kelestarian sumber daya tersebut. Syaukat dan Sumarti (2004) menjelaskan bahwa, sumber-sumber daya saing ekonomi lokal antara lain : lahan, tenaga kerja, dan modal.

Berdasarkan pendapat tersebut di atas pengembangan ekonomi lokal melalui kegiatan usaha simpan pinjam sangat dipengaruhi oleh sumberdaya yang dimiliki komunitas. Menurut Sumodiningrat (2001) bahwa dalam penyaluran kredit kepada pengusaha kecil menengah harus melalui lembaga keuangan pedesaan yang sesuai dengan pola usaha masyarakatnya. Untuk itu diperlukan syarat-syarat bagi lembaga keuangan pedesaan 
supaya mampu berkembang, yaitu: (1) harus mencerminkan kebutuhan masyarakat; (2) mudah diawasi, dipantau dan dikelola oleh masyarakat setempat; (3) menguntungkan bagi masyarakat maupun lembaga; (4) memberikan pelayanan keuangan yang menjangkau masyarakat esuai kondisi masyarakat setempat.

Menurut Syaukat dan Hendrakusumaatmaja (2004), untuk dapat mengukur keberhasilan suatu pembangunan khususnya dalam pengembangan ekonomi lokal dapat menggunakan beberapa indikatorindikator keberhasilan, yaitu :

\section{a. Indikator Masukan}

Adanya kebijakan pemerintah pusat dan daerah untuk programprogram terpadu yang berwawasan penanggulangan kemiskinan yang berkelanjutan pada instansi pemerintah, swasta, dan masyarakat. Kebijakan ini haruslah ditopang dengan adanya alokasi dana dari APBN maupun Anggran Pendapatan dan Belanja Daerah (APBD) untuk program-program tersebut.

\section{b. Indikator Proses}

Terselenggaranya kegiatan-kegiatan program penanggulangan kemiskinan sesuai dengan alokasi jadwal kegiatan dan anggaran dengan mempertimbangkan kesinambungan program.

\section{c. Indikator Keluaran}

- Indikator Penghasilan

Jika penghasilan kelompok masyarakat men ingkat dari waktu ke waktu, ini menunjukkan adanya perbaikan tingkat kesejahteraan. Indikatoenya adalah pendapatan perkapita penduduk dan persentase penduduk miskin.

- Indikator Ketahanan dan Kecukupan Pangan

Dapat dilihat dari sejauh mana ada peningkatan konsumsi bahan pangan, indikatornya antara lain: ketersediaan pangan yang mencukupi, distribusi pangan yang lancar dan konsumsi pangan yang memadai, serta proporsi pengeluaran rumah tangga untuk bahan bukan makanan.

- Indikator Pendidikan

Indikator sektor pendidikan untuk mengukur keberhasilan penanggulangan kemiskinan adalah: partisipasi sekolah dan putus sekolah, dan proporsi orang dewasa yang buta huruf.

- Indikator Kesehatan.

Indikator sektor kesehatan untuk mengukur keberhasilan antara lain: angka kematian bayi, angka kematian ibu melahirkan dan angka harapan hidup. 
- Indikator Kesempatan Kerja

Indikator kesempatan kerja sebagai alat untuk mengukur keberhasilan penanggulangan kemiskinan antara lain: tingkat upah riil; proporsi tenaga kerja di sektor formal; jumlah pengangguran; tenaga kerja dibawah umur.

- Indikator Sarana dan Prasarana

Indikator sarana dan prasarana yang penting adalah: ketersediaan transportasi, penerangan (listrik), informasi dan ketersedian akses untuk memperoleh air bersih, air minum, dan san itasi yang sehat.

- Indeks Pembangunan Jender

Merupakan indeks yang menunjukkan upaya untuk mengurangi kesenjangan dalam pencapaian kualitas hidup antara laki-laki dan perempuan dalam pembangunan. Indeks Pembangunan Jender antara lain: angka harapan hidup laki-laki dan perempuan; persentase tingkat melek huruf laki-laki dan perempuan; rata-rata lamanya sekolah laki-laki dan perempuan; persentase konstribusi pendapatan laki-laki dan perempuan.

\section{Pemberdayaan Masyarakat}

Pemberdayaan adalah upaya membangun daya saing, dengan mendorong, memotivasi, dan membangkitkan aksi yang dimiliki masyarakat serta berupaya untuk mengembangkannya (Kartasasmita 1996) dalam pemberdayaan tersebut menurut (Suharto 2005) menunjuk pada kemampuan orang, khususnya kelompok rentan dan lemah sehingga mereka memiliki kekuatan atau kemampuan dalam : 1). Memenuhi kebutuhan dasarnya sehingga mereka memiliki kebebasan (freedom, dalam arti bukan saja bebas mengemukakan pendapat, melainkan bebas dari kelaparan, bebas dari kebodohan, bebas dari kesakitan). 2). Menjangkau sumber-sumber produktif yang memungkinkan mereka dapat meningkatkan pendapatannya dan memperoleh barang-barang dan jasajasa yang mereka perlukan. 3). Berpartisipasi dalam proses pembangunan dan keputusan-keputusan yang mempengaruhi mereka.

Pemberdayaan dengan demikian merupakan sebuah proses dan tujuan. Sebagai proses, pemberdayaan adalah serangkaian kegiatan untuk memperkuat kekuasaan atau keberdayaan kelompok lemah dalam masyarakat, termasuk individu-individu yang mengalami masalah kemiskinan. Pemberdayaan sebagai tujuan, menunjuk pada keadaan atau hasil yang ingin dicapai oleh sebuah perubahan sosial yaitu; masyarakat berdaya, memiliki kekuasaan atau mempunyai pengetahuan dan kemampuan dalam memenuhi kebutuhan hidupnya baik yang bersifat 
fisik, ekonomi, maupun sosial seperti memiliki kepercayaan diri, mampu menyampaikan aspirasi, mempunyai mata pencaharian, berpartisipasi dalam kegiatan sosial, dan mandiri dalam melaksanakan tugas-tugas kehidupannya. Tiga cara pemberdayaan ekonomi menurut (Kartasasmita 1996) antara lain :1). Menciptakan iklim yang memungkinkan lapisan masyarakat berkembang. 2). Memperbaiki potensi atau daya yang dimiliki. 3). Memberikan perlindungan bagi si lemah, mencegah persaingan tidak seimbang dan eksploitasi . Pemberdayaan masyarakat bukan menjadikan mereka tergantung pada pemberian, tetapi merupakan hasil usaha sendiri yang dapat dipertukarkan sebagai upaya memenuhi kebutuhan ekonominya.

\section{Penguatan Kapasitas}

Penguatan adalah suatu proses upaya yang sistematis menjadikan lembaga suatu masyarakat menjadi lebih baik, dinamis, berdaya dan kuat dalam menghadapi berbagai pemenuhan kebutuhan dan tantangan atau hambatan yang dapat mempengaruhi eksistensinya. Penguatan kapasitas merupakan suatu proses peningkatan atau perubahan perilaku individu, organisasi dan sistem masyarakat dalam mencapai tujuan yang telah ditentukan secara efektif dan efisien. Merujuk pendapat (Sumpeno 2002), penguatan kapasitas berarti terjadi perubahan perilaku untuk : 1). Meningkatkan kemampuan individu dalam pengetahuan, keterampilan dan sikap; 2). Meningkatkan kemampuan kelembagaan dalam organisasi dan manajemen, keuangan dan budaya; 3). Meningkatkan kemampuan masyarakat dalam kemandirian, keswadayaan dan mengantisipasi perubahan. Penguatan kelembagaan kelompok sangat diperlukan, karena dengan penguatan kapasitas masyarakat/usaha mikro kecil sebagai anggota bisa mengembangkan modal sosial, seperti yang dikemukakan oleh (Rubin \& Rubin 1992) bahwa "pengembangan kapasitas adalah bagaimana menciptakan kemampuan untuk menemukan kekurangan yang ada pada dirinya dan ada upaya untuk meningkatkan kekurangannya tersebut" .

Hasil yang diharapkan dengan adanya penguatan kapasitas menurut (Sumpeno 2002) adalah :1). Penguatan individu, organisasi dan masyarakat. 2). Terbentuknya model pengembangan kapasitas dan progra 3). Terbangunnya sinergisitas pelaku dan kelembagaan.

Pengertian pengembangan kelembagaan menurut (Israel 1992) adalah proses untuk memperbaiki kemampuan lembaga guna mengefektifkan penggunaan sumber daya manusia dengan keuangan yang tersedia. Lebih lanjut(Rubin \& Rubin 1992) mengemukakan bahwa pengembangan kapasitas masyarakat miskin dapat dilakukan dengan melalui pengembangan kelembagaan masyarakat dimana kelembagaan tersebut menciptakan dan 
membangun perasaan anggota untuk membangkitkan kapasitas lembaga dalam pemecahan masalah. Penguatan kapasitas lembaga simpan pinjam dapat dicapai melalui komponen kepercayaan, kerjasama dan kemitraan sehingga melalui pemberdayaan anggota dan lembaga akan dapat meningkatkan kemampuan atas pengetahuan, keterampilan dan sikap disamping dapat meningkatkan kemampuan lembaga dan kemampuan masyarakat miskin sebagai anggotanya.

\section{Kinerja Kelompok}

Analisis terhadap kinerja akan membantu menggambarkan bagaimana prospek suatu kelompok dapat berkembang. Kinerja mengacu pada tingkat kemampuan pelaksanaan tugas dengan standar perbandingan ideal antara pelaksanaan tugas dan yang diharapkan (perencanaan) dengan pelaksanaan tugas yang telah dilaksanakan (evaluasi). Pengertian kinerja merujuk kamus Bahasa Indonesia, (Purwadarminta 1992) menjelaskan kinerja sebagai keterampilan dan kemampuan yang dimiliki seseorang dimunculkan melalui perbuatan. Kinerja menurut (Bernadin \& Russel dikutip dalam Mulyono 1993) menjelaskan penilaian kinerja merupakan suatu cara untuk mengukur kontribusi individu anggota organisasi terhadap organisasinya. Kinerja juga diartikan perilaku yang diperagakan secara aktual oleh individu sebagai respon terhadap pekerjaan yang diberikan kepadanya, sehingga kinerja dapat dilihat dari hasil kerja, derajat kecepatan kerja dan kualitas kerja. Kinerja sebagai unsur kegiatan pengendalian program pemberdayaan masyarakat atau usaha mikro kecil bertumpu pada pemantauan indikator kinerja sesuai tujuan khusus yang akan dicapai, baik yang indikator yang bersifat obyektif maupun subyektif.

Pengertian kinerja dari uraian di atas bisa disebut sebagai kualitas penatalaksanaan lembaga meliputi sistem pengorganisasian terdiri atas input, proses dan output pelaksanaan manajemen lembaga simpan pinjam. Pengertian tersebut mencakup; 1) Input meliputi sarana, bahan, pengurus dan organisasi, sedangkan proses meliputi sosialisasi program perguliran dana simpan pinjam, pemberian kredit serta kegiatan pelaporan dan tindak lanjutnya, 2) Output yang dimaksud adalah kegiatan pelaporan perguliran dana serta laporan kegiatan pengorganisasian lembaga simpan pinjam. Penjelasan kinerja tersebut bisa dikatakan bahwa, indikator kinerja lembaga simpan pinjam berarti suatu kegiatan yang dapat memberi petunjuk baik buruknya kegiatan input, proses dan output pelaksanaan kegiatan lembaga simpan pinjam. Kinerja bisa disimpulkan sebagai aspek yang berpengaruh terhadap maju dan mundurnya lembaga yaitu, kinerja pengurus dan anggota dari lembaga simpan pinjam. Dikatakan berpengaruh sebab masing-masing anggota suatu lembaga secara spesifik bisa muncul kinerja yang berbeda dan akibat dari kinerja anggota tersebut akan berpengaruh 
terhadap hubungan kerjasama di dalam lembaga. Kinerja sebagai alat ukur digunakan untuk melihat maju dan mundurnya lembaga dilihat dari pencapaian target, efisiensi dan efektivitas dari pengelolaan usaha simpan pinjam yang sesuai dengan penjelasan oleh (Mulyono 1993), yaitu :1). Derajat pencapaian tujuan pokok, 2) Seberapa efisien sumberdaya (dapat berupa masukan, antara lain tenaga kerja, material, jasa pelayanan yang dibeli dan modal) digunakan untuk menghasilkan keluaran yang bermanfaat, dalam arti hasil yang dicapai sesuai dengan yang diharapkan sebelumnya. 3). Perbandingan mengenai performa organisasi dari waktu terdahulu dengan waktu sekarang, menunjukkan penurunan, statis atau berkembang.

\section{Pengembangan Kapasitas dalam Penguatan Kelembagaan}

Kelembagaan sosial merupakan terjemahan langsung istilah social institution. Akan tetapi ada pula yang menggunakan istilah pranata sosial untuk istilah social institution tersebut, yang menunjuk pada adanya unsur-unsur yang mengatur perilaku masyarakat. Koentjaraningrat dalam Nasdian dan Utomo (2004) mengatakan pranata sosial sebagai suatu sistem tata kelakuan dan hubungan yang berpusat kepada aktivitas-aktivitas untuk memenuhi kebutuhan khusus dalam kehidupan masyarakat. Bertrand dalam Nasdian dan Utomo (2004) mendefinisikan kelembagaan sosial sebagai tata abstraksi yang lebih tinggi dari group, organisasi, dan sistem sosial lainnya. Menurut Syahyuti (2003), di dalam setiap kelembagaan terdapat dua bagian yang membangun kelembagaan tersebut. Kedua bagian tersebut adalah aspek-aspek kelembagaan dan aspek-aspek organisasi. Pembedaan dalam melihat kelembagaan melalui aspek kelembagaan dan aspek organisasi bertujuan agar dapat menganalisa kelembagaan tersebut secara mendalam. Aspek kelembagaan merupakan sisi dinamis yang lebih bersifat kultural dari suatu kelembagaan, sedangkan aspek keorganisasian merupakan sisi statisnya yang lebih bersifat struktural. Jika aspek kelembagaan fokus utama kajian adalah perilaku dengan inti kajiannya adalah nilai (value), aturan (rule), dan norma (norm), maka fokus utama dari aspek keorganisasian adalah struktur dengan inti kajiannya pada peran (roles).

Menurut Eade (1997) dalam Nasdian dan Utomo (2004), pengembangan kapasitas kelembagaan terfokus pada lima isu pokok berikut :

a. Pengembangan kapasitas sering digunakan secara sederhana untuk menjadikan suatu lembaga lebih efektif mengimplementasikan proyekproyek pembangunan. Kelembagaan dengan demikian merupakan instrumen untuk mencapai tujuan tertentu.

b. Pengembangan kapasitas dapat juga menunjuk pada upaya mendukung organisasi untuk menjadi katalis dialog politik dan atau memberikan kontribusi dalam mencari alternatif pembangunan. Pandangan ini 
menekankan peran mendemokratisasikan organisasi non pemerintah dan organisasi berbasiskan masyarakat dalam "masyarakat madani".

c. Jika pengembangan kapasitas adalah suatu cara untuk mencapai tujuan, kemudian yang dimaksudkan oleh lembaga-lembaga yang ikut serta, maka fokus pengembangan adalah mengembangkan hubungan antara struktur, proses, dan kegiatan organisasi yang menerima dukungan dan kualitas serta jumlah output dari hasil kerjanya.

d. Jika pengembangan kapasitas adalah tujuan akhir itu sendiri, maka fokusnya adalah misi organisasi yang berimbang, dan pertautannya dengan lingkungan eksternalnya, strukturnya dan aktivitasnya.

e. Jika pengembangan kapasitas adalah suatu proses penyesuaian, maka fokusnya adalah membantu mitra kerja menjadi lebih mandiri dan aktor otonom dalam hubungan jangka panjang atau penyertaan donor dan agen -agen yang relevan lainnya.

Keberhasilan suatu kelembagaan dipengaruhi oleh kuatnya kepemimpinan serta adanya manajemen yang baik dalam kelembagaan tersebut. Hal ini sesuai dengan yang dikemukakan oleh Israel (1992) bahwa faktor-faktor yang mempengaruhi keberhasilan atau kegagalan kekembagaan adalah:

1. Faktor-faktor eksogen: faktor yang mempengaruhi seluruh negara, wilayah atau sektor untuk periode tertentu, misalnya: banjir, kekeringan, peperangan, krisis ekonomi, perubahan-perubahan penting dalam kebijakan ekonomi.

2. Kepemimpinan individu-individu yang menonjol.

3. Manajemen yang baik mulai dari perencanaan, pengorganisasiaan, pelaksanaan serta pengawasan.

4. Komitmen.

Pemberdayaan masyarakat selain meliputi penguatan individu anggota masyarakat sendiri, juga meliputi penguatan pranata. Pranata atau kelembagaan yang dimaksud baik berupa kelembagaan atau yang bersifat "badan" atau organisasi, maupun kelembagaan sosial. Kelembagaan sosial disini merupakan bentuk nyata dari pemanfaatan modal sosial serta kemandirian yang dimiliki masyarakat.

\section{METODE PENELITIAN}

Berdasarkan tujuan kajian, data yang dibutuhkan, sumber data dan teknik pengumpulan data ditampilkan dalam tabel 1. berikut ini : 
Tabel 1. Tujuan, Jenis Data, sumber data dan Teknik Pengumpulan data

\begin{tabular}{|c|c|c|c|c|}
\hline No. & Tujuan & Jenis Data & Sumber Data & $\begin{array}{c}\text { Teknik } \\
\text { Pengumpulan } \\
\text { Data }\end{array}$ \\
\hline 1. & $\begin{array}{l}\text { Identifikasi } \\
\text { potensi } \\
\text { pengembang- } \\
\text { an ekonomi } \\
\text { lokal }\end{array}$ & $\begin{array}{l}\text { Sumber daya } \\
\text { alam, seumber } \\
\text { daya manusia, } \\
\text { kelembagaan } \\
\text { ekonomi. }\end{array}$ & $\begin{array}{l}\text { Pengurus, anggota } \\
\text { kelompok PEW, } \\
\text { tokoh masyarakat, } \\
\text { aparat desa dan } \\
\text { pemerintah }\end{array}$ & $\begin{array}{l}\text { Observasi, } \\
\text { wawancara, } \\
\text { studi dokumen, } \\
\text { kuesioner }\end{array}$ \\
\hline 2. & $\begin{array}{l}\text { Identifikasi } \\
\text { kapasitas } \\
\text { kelembagaan } \\
\text { dan anggota } \\
\text { kelompok } \\
\text { PEW }\end{array}$ & $\begin{array}{l}\text { Karakteristik } \\
\text { anggota, } \\
\text { pengetahuan } \\
\text { dan ketrampilan, } \\
\text { kapasitas } \\
\text { pengurus, norma/ } \\
\text { aturan kelompok, } \\
\text { kepemimpinan } \\
\text { dan manajemen }\end{array}$ & $\begin{array}{l}\text { Pengurus, anggota } \\
\text { dan fasilitator } \\
\text { kelompok PEW }\end{array}$ & $\begin{array}{l}\text { Observasi, } \\
\text { wawancara, } \\
\text { studi dokumen, } \\
\text { kuesioner }\end{array}$ \\
\hline 3. & $\begin{array}{l}\text { Evaluasi } \\
\text { kinerja } \\
\text { kelompok } \\
\text { PEW }\end{array}$ & $\begin{array}{l}\text { Perkembangan } \\
\text { modal, } \\
\text { perkembangan } \\
\text { anggota, } \\
\text { perkembangan } \\
\text { kegiatan, } \\
\text { hambatan } \\
\text { kegiatan dan } \\
\text { administrasi }\end{array}$ & $\begin{array}{l}\text { Pengurus, anggota } \\
\text { kelompok PEW, } \\
\text { tokoh masyarakat, } \\
\text { aparat desa dan } \\
\text { pemerintah }\end{array}$ & $\begin{array}{l}\text { Wawancara, } \\
\text { studi dokumen, } \\
\text { kuesioner }\end{array}$ \\
\hline 4. & $\begin{array}{l}\text { Rumusan } \\
\text { program } \\
\text { penguatan } \\
\text { kapasitas } \\
\text { kelembagaan } \\
\text { kelompok }\end{array}$ & $\begin{array}{l}\text { Analisis faktor } \\
\text { internal (kekuatan } \\
\text { dan kelemahan) } \\
\text { Analisis faktor } \\
\text { eksternal } \\
\text { (Kesempatan dan } \\
\text { Ancaman) }\end{array}$ & $\begin{array}{l}\text { Pengurus, anggota } \\
\text { kelompok PEW } \\
\text { dan stockholder }\end{array}$ & $\begin{array}{l}\text { Wawancara, } \\
\text { studi dokumen }\end{array}$ \\
\hline
\end{tabular}

Menurut Miles dan Huberman (1992) dalam Sitorus dan Agusta (2004), analisis data kualitatif dilakukan melalui tiga alur : reduksi data, penyajian data dan penarikan kesimpulan. 
1. Reduksi Data

Dengan kondisi data yang diperoleh dari lapangan yang jumlahnya tidak terbatas, maka peneliti harus melakukan reduksi, yaitu hanya memilih hal-hal pokok dan tema-tema yang relevan dengan fokus kajian. Data yang direduksi itu akan memberikan gambaran yang lebih tajam tentang hasil kajian dan dapat membantu dalam kode-kode tertentu.

2. Penyajian Data

Yaitu menyajikan data dalam bentuk matriks, network dan sebagainya yang memungkinkan data hasil kajian tidak tercampur dengan setumpuk data yang belum diolah.

3. Penarikan Kesimpulan dan Verifikasi

Yaitu upaya untuk mencari pola, model, tema atau hal-hal yang sering muncul sehingga di dapat suatu kesimpulan yang semakin lama menjadi semakin jelas seiring dengan semakin banyak data yang diperoleh.

Strategi kajian dalam analisis masalah ini menggunakan Logical Framework Analysis. Penggunaan alat analisis Logical Framework untuk mempermudah dalam menganalisis masalah, tujuan hingga penyusunan program. Tahapan-tahapan dalam Logical Framework Analysis (Sumardjo \& Saharudin 2003) adalah : Tahap Pertama, melaksanakan analisis permasalahan berdasarkan informasi yang diberikan masyarakat . Tahap Kedua, melaksanakan analisis tujuan berdasarkan analisis permasalahan yang telah dirumuskan. Tahap Ketiga, melaksanakan matrik alternatif kegiatan, berdasarkan analisis tujuan dirumuskan analisis alternatif strategi penguatan kapasitas kelembagaan ekonomi lokal. Tahap Keempat, menyusun analisis pihak terkait berdasakan identifikasi yang telah dilakukan. Tahap Kelima, menyusun rencana kegiatan.

\section{HASIL YANG DIPEROLEH}

\section{Identifikasi potensi Pengembangan Ekonomi lokal}

Pembangunan ekonomi Kota Yogyakarta merupakan rangkaian kegiatan pembangunan yang bertujuan untuk meningkatkan peranan sektor perdagangan, industri, koperasi dan jasa sehingga dapat terwujud kegiatan yang menggairahkan kehidupan ekonomi kota, memperluas lapangan kerja dan lapangan berusaha serta meningkatkan pendapatan masyarakat secara lebih merata. Untuk mencapai tujuan tersebut dilaksanakan dengan kebijakan :

a. Mengembangkan ekonomi kerakyatan yang bertumpu pada usaha mikro kecil menengah dan koperasi (UMKMK)

b. Mengembangkan lingkungan usaha dan iklim investasi 
c. Mendorong usaha yang berkelanjutan dan pemerataan ekonomi dengan lokomotif bidang pendidikan dan pariwisata.

Potensi usaha mikro kecil dan menengah (UMKM) di Kota Yogyakarta tercatat sebanyak 18.234 unit usaha yang terdiri dari sektor industri sekitar 4.569 unit usaha dan sektor perdagangan dan jasa mencapai sekitar 13.126 unit usaha, dan koperasi 539 unit. Berbagai produk yang dihasilkan oleh usaha mikro kecil dan menengah merupakan produk unggulan yang telah mampu menembus pasar secara luas baik di tingkat lokal, regional, nasional maupun internasional sehingga pemerintah perlu memfasilitasi secara terus menerus agar keberadaan usaha mikro kecil dan menengah dapat semakin berkembang sehingga dapat memberikan kontribusi bagi pengembangan perekonomian di Kota Yogyakarta. Berbagai permasalahan masih dihadapi oleh usaha mikro kecil dan menengah (UMKM). Oleh

karena itu peran pemerintah sangat diperlukan untuk dapat memfasilitasi UMKM agar keberadaannya dapat dipertahankan dan dikembangkan sehingga memiliki daya tahan dan daya saing yang kuat dalam menghadapi era pasar bebas mendatang.

\section{a. Program Pemberdayaan Ekonomi Berbasis Kewilayahan (PEW)}

Pada tahun 2006, Pemerintah Kota Yogyakarta melalui Dinas Perindagkop telah memberikan penguatan permodalan melalui kegiatan Pemberdayaan Ekonomi Berbasis Kewilayahan (PEW) kepada para pengusaha mikro dan kecil yang tergabung dalam kelompok - kelompok di 5 kecamatan. Pada awalnya, direncanakan permodalan ini ditujukan kepada 14 kecamatan se-Kota Yogyakarta. Namun dengan adanya peristiwa gempa 26 Mei 2006, maka permodalan dialihkan kepada 5 kecamatan korban gempa terparah di Kota Yogyakarta, yakni Kecamatan Kotagede, Umbulharjo, Mergangsan, Mantrijeron, dan Gondokusuman. Tercatat sebanyak 28 kelompok usaha mikro kecil yang saat itu menerima guliran dana PEW, dengan total dana sebesar Rp.1.048.000.000,--

Tahun 2007, dana PEW kembali diluncurkan dengan sasaran 9 kecamatan yang belum menerima PEW di tahun 2006, yakni Kecamatan Kraton, Gondomanan, Gedongtengen, Danurejan, Jetis, Tegalrejo, Wirobrajan, Ngampilan dan Pakualaman. Penerima dana PEW 2007 adalah sebanyak 23 kelompok dengan total penerimaan sebesar Rp.912.000.000,-. Bentuk dana bergulir PEW 2006 dan 2007 adalah pinjaman lunak bersyarat, di mana kelompok penerima dana PEW memiliki kewajiban untuk mengembalikan dana tersebut ke Kas Daerah sesuai dengan ketentuan. Dana bergulir PEW 2008, 2009, 2010, 2011 dan yang akan dilaksanakan tahun 2012 berbentuk hibah kepada kelompok dan bergulir di internal kelompok, sehingga anggota kelompok memiliki kewajiban untuk mengembalikan dana kepada kelompok, namun kelompok tidak memiliki kewajiban kepada pemerintah 
untuk mengembalikan dana tersebut. Kelompok diberi kewenangan untuk mengelola dana tersebut demi perkembangan kelompok dan anggota kelompoknya sesuai dengan kesepakatan dalam kelompok. Untuk diketahui, jumlah penerima dana PEW tahun 2008 adalah sebanyak 225 kelompok dengan total dana Rp.2.250.000.000,-. PEW 2009 berjumlah 421 kelompok dengan total dana Rp.4.325.000.000,-. Dan PEW 2010 berjumlah 225 kelompok dengan total dana Rp.2.250.000.000,- serta PEW 2011 sebanyak 225 kelompok dengan total dana Rp.2.250.000.000. Sampai dengan saat ini, total jumlah kelompok PEW dari tahun 2006 sampai dengan tahun 2011 berjumlah 1.147 kelompok dengan dana Rp.13.035.000.000,--

Tujuan Program adalah Memberikan fasilitasi kepada usaha mikro kecil dan menengah dalam mengembangkan usahanya melalui penguatan permodalan dengan pola bergulir di internal kelompok. Sasaran kegiatan ini adalah komunitas usaha mikro kecil dan menengah yang tergabung dalam kelompok di 45 kelurahan se-Kota Yogyakarta. Hasil dan manfaat yang ingin dicapai adalah terpenuhinya kebutuhan permodalan bagi usaha mikro kecil dan menengah di 45 kelurahan se-Kota Yogyakarta sehingga usaha dan kegiatannya semakin berkembang. Jenis bantuan yang diberikan adalah bantuan hibah bersyarat yang akan dipergunakan untuk penguatan permodalan dan peningkatan sarana prasarana usaha bagi usaha mikro kecil menengah yang tergabung dalam kelompok-kelompok UMKM di 45 kelurahan se- Kota Yogyakarta.

\section{b. Kelembagaan}

Untuk mengelola bantuan pengembangan ekonomi wilayah berbasis kelurahan di Kota Yogyakarta diperlukan lembaga-lembaga pengelola sebagai berikut:

- Tim Koordinasi Bantuan Pengembangan Ekonomi Berbasis Kewilayahan Kota Yogyakarta yang dibentuk dengan Keputusan Walikota Yogyakarta. Tim ini diketuai oleh Kepala Dinas Perindustrian Perdagangan Koperasi dan Pertanian Kota Yogyakarta dengan anggota yang berasal dari unsur Dinas Perindustrian Perdagangan Koperasi dan Pertanian Kota Yogyakarta, Bappeda Kota Yogyakarta, DPDPK Kota Yogyakarta, Dinas Kesejahteraan Sosial Tenaga Kerja dan Transmigrasi Kota Yogyakarta, Bagian Hukum Sekretariat Daerah Kota Yogyakarta, Bank Pelaksana, Kecamatan dan Lembaga Swadaya Masyarakat (LSM), dengan tugas dan tanggung jawab sebagai berikut :

1) Mempersiapkan Peraturan Walikota Yogyakarta tentang Petunjuk Umum pelaksanaan kegiatan.

2) Mempersiapkan Peraturan Kepala Dinas Perindustrian Perdagangan Koperasi dan Pertanian Kota Yogyakarta tentang Petunjuk Teknis Pelaksanaan kegiatan. 
3) Mensosialisasikan Peraturan Walikota Yogyakarta dan Peraturan Kepala Dinas Perindustrian Perdagangan Koperasi dan Pertanian tentang Petunjuk Umum dan Petunjuk Teknis pelaksanaan kegiatan.

4) Menerima dan mengevaluasi proposal dari kelompok calon penerima bantuan.

5) Memfasilitasi pencairan bantuan dari Pemerintah Kota Yogyakarta kepada kelompok penerima bantuan.

6) Memonitor pelaksanaan penyaluran dan pengguliran bantuan kepada para anggota kelompok penerima bantuan.

7) Melaporkan pelaksanaan tugas dan tanggung jawabnya kepada Walikota Yogyakarta melalui Kepala Dinas Perindustrian Perdagangan Koperasi dan Pertanian Kota Yogyakarta.

- Kelompok usaha mikro kecil dan menengah penerima bantuan.

Kelompok ini memiliki tugas dan tanggung jawab sebagai berikut :

1) Mensosialisasikan program bantuan kepada para anggotanya.

2) Mengajukan proposal pencairan bantuan kepada Walikota Yogyakarta melalui Kepala Dnas Perindagkoptan Kota Yogyakarta.

3) Membuka rekening di Bank Pelaksana.

4) Menerima dan mengevaluasi permohonan pencairan bantuan dari para anggota.

5) Menyetujui atau menolak permohonan pencairan bantuan dari para anggota dengan berpedoman pada petunjuk teknis.

6) Mencairkan bantuan kepada para anggota sesuai petunjuk teknis.

7) Mengelola dan mengadministrasikan perguliran bantuan di kelompok yang bersangkutan.

8) Melaporkan pelaksanaan tugas dan tanggung jawabnya kepada Kepala Dinas Perindustrian Perdagangan Koperasi dan Pertanian Kota Yogyakarta.

\section{c. Profil Kelompok PEW di Kelurahan Pringgokusuman}

Berdasarkan data yang diperoleh dari seksi Pemberdayaan Masyarakat Kecamatan Gedongtengen, diketahui bahwa jenis usaha mikro kecil di kelurahan gedontengen adalah usaha jasa berjumlah 2 , toko ada 1, niaga ada 4, percetakan ada 1, warung sembako 2, warung makan 3 , makanan tradisional 18 dan yang paling banyak adalah usaha kerajinan yang berjumlah 24 seperti terlihat pada gambar 1 berikut ini: 


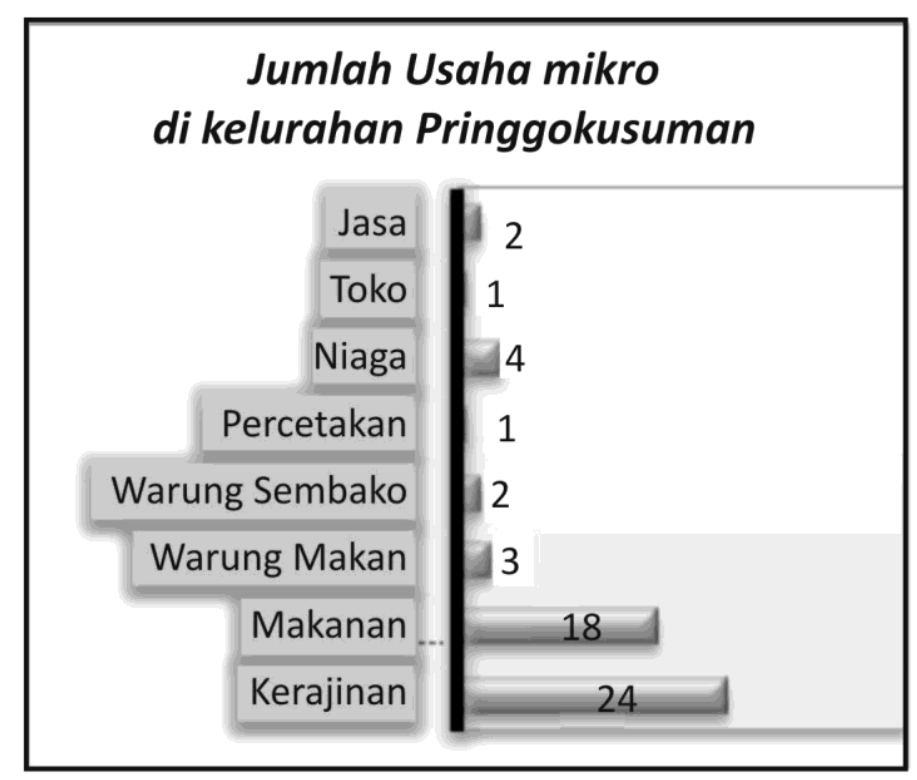

Gambar 1. Jumlah dan jenis usaha mikro kecil di Pringgokusuman

Di Kelurahan Pringgokusuman , Kecamatan Gedongtengen terdapat 33 kelompok yang menerima bantuan penguatan permodalan melalui kegiatan Pemberdayaan Ekonomi Berbasis Kewilayahan (PEW) serta tercantum dalam tabel 2

Tabel 2. Profil Kelompok Penerima bantuan Permodalan program PEW

\begin{tabular}{|c|l|c|c|c|}
\hline No. & \multicolumn{1}{|c|}{ Nama Kelompok } & $\begin{array}{c}\text { Tahun } \\
\text { Perolehan }\end{array}$ & $\begin{array}{c}\text { Jumlah } \\
\text { Anggota }\end{array}$ & $\begin{array}{c}\text { Bantuan Dana Bergilir } \\
\text { Program PEW }\end{array}$ \\
\hline 1 & Aneka Warna & 2008 & 10 & Rp. $\quad 10.000 .000,00$ \\
\hline 2 & Maju Mapan & 2008 & 10 & Rp. $\quad 10.000 .000,00$ \\
\hline 3 & Sidodadi & 2008 & 10 & Rp. $\quad 10.000 .000,00$ \\
\hline 4 & KPD Usaha Kerja Mandiri & 2008 & 10 & Rp. $\quad 10.000 .000,00$ \\
\hline 5 & Bina Mandiri & 2008 & 10 & Rp. $\quad 10.000 .000,00$ \\
\hline 6 & Kube Mekar Abadi & 2009 & 15 & Rp. $\quad 10.000 .000,00$ \\
\hline 7 & Sekar Asri & 2009 & 15 & Rp. $\quad 10.000 .000,00$ \\
\hline 8 & Maju Sejahtera & 2009 & 10 & Rp. $\quad 10.000 .000,00$ \\
\hline 9 & Hasanah & 2009 & 10 & Rp. $\quad 10.000 .000,00$ \\
\hline 10 & Berkah Sejahtera & 2009 & 10 & Rp. $\quad 10.000 .000,00$ \\
\hline 11 & Tunas Harapan & 2009 & 10 & Rp. $\quad 10.000 .000,00$ \\
\hline 12 & Sejahtera Mandiri & 2009 & 11 & Rp. $\quad 10.000 .000,00$ \\
\hline 13 & Lestari & 2009 & 10 & Rp. $\quad 10.000 .000,00$ \\
\hline 14 & Wargo Utama & 2009 & 12 & Rp. $\quad 10.000 .000,00$ \\
\hline 15 & Ngudi Mulyo & 2009 & 10 & Rp. $\quad 10.000 .000,00$ \\
\hline 16 & Maju Sejahtera I & 2010 & 10 & Rp. $\quad 10.000 .000,00$ \\
\hline 17 & Hidayah & 2010 & 10 & Rp. $\quad 10.000 .000,00$ \\
\hline
\end{tabular}




\begin{tabular}{|c|l|c|c|c|}
\hline No. & \multicolumn{1}{|c|}{ Nama Kelompok } & $\begin{array}{c}\text { Tahun } \\
\text { Perolehan }\end{array}$ & $\begin{array}{c}\text { Jumlah } \\
\text { Anggota }\end{array}$ & $\begin{array}{c}\text { Bantuan Dana Bergilir } \\
\text { Program PEW }\end{array}$ \\
\hline 18 & Daimah & 2010 & 10 & Rp. $\quad 10.000 .000,00$ \\
\hline 19 & Pengen Makmur & 2010 & 10 & Rp. $\quad 10.000 .000,00$ \\
\hline 20 & Dewi Sri & 2010 & 10 & Rp. $\quad 10.000 .000,00$ \\
\hline 21 & Aneka Usaha & 2011 & 10 & Rp. $\quad 10.000 .000,00$ \\
\hline 22 & Sri Makmur & 2011 & 10 & Rp. $\quad 10.000 .000,00$ \\
\hline 23 & Khasanah & 2011 & 10 & Rp. $\quad 10.000 .000,00$ \\
\hline 24 & Maju Lancar & 2011 & 10 & Rp. $\quad 10.000 .000,00$ \\
\hline 25 & Aisyah Notoyudan & 2011 & 10 & Rp. $\quad 10.000 .000,00$ \\
\hline 26 & Maju Jaya & 2011 & 10 & Rp. $\quad 10.000 .000,00$ \\
\hline 27 & Daimah 2 & 2012 & 10 & Rp. $\quad 10.000 .000,00$ \\
\hline 28 & Karya Mandiri & 2012 & 10 & Rp. $\quad 10.000 .000,00$ \\
\hline 29 & Sumber Rejeki & 2012 & 10 & Rp. $\quad 10.000 .000,00$ \\
\hline 30 & Sanggar Karya Usaha & 2012 & 10 & Rp. $\quad 10.000 .000,00$ \\
\hline 31 & Sukses & 2012 & 10 & Rp. $\quad 10.000 .000,00$ \\
\hline 32 & Kariya Bersatu & 2012 & 10 & Rp. $\quad 10.000 .000,00$ \\
\hline 33 & Sedyo Makmur & 2012 & 10 & Rp. $\quad 10.000 .000,00$ \\
\hline & Jumlah & & 343 & Rp. $330.000 .000,00$ \\
\hline
\end{tabular}

Terdapat 5 kelompok yang memperoleh bantuan penguatan modal tahun 2008, 10 kelompok pada tahun 2009 , tahun 2010 ada 5 kelompok, tahun 2011 terdapat 6 kelompok, dan tahun 2012 terdapat 7 kelompok penerima bantuan penguatan penguatan permodalan melalui kegiatan Pemberdayaan Ekonomi Berbasis Kewilayahan (PEW) seperti dapat dilihat dalam gambar 2 


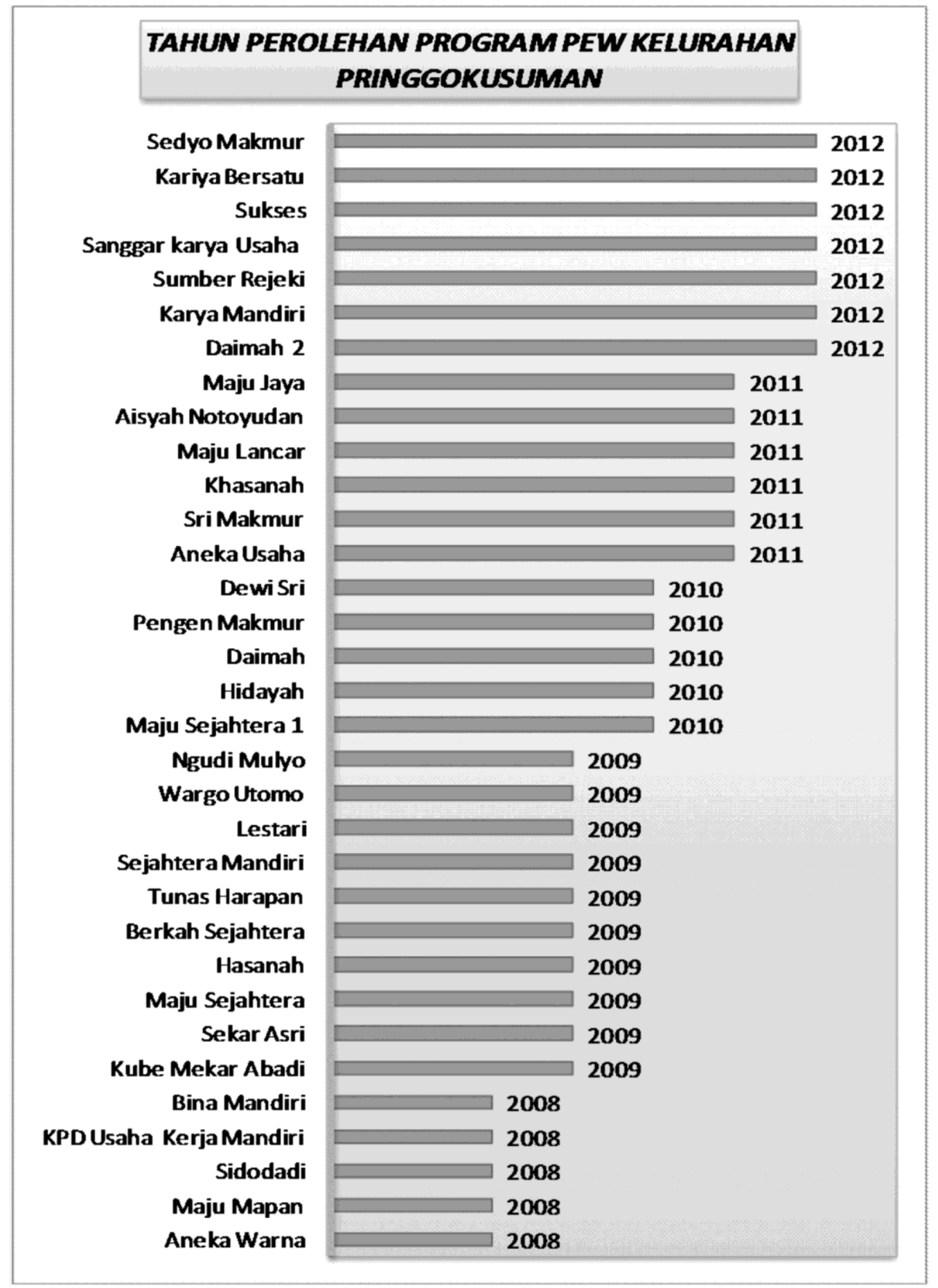

Gambar 2. Kelompok PEW dan tahun perolehan bantuan

Selanjutnya jumlah dana PEW yang telah digulirkan kepada kelompok PEW di kelurahan Pringgokusuman dari tahun 2008 sampai tahun 2012 dapat dilihat dalam gambar 3 . 


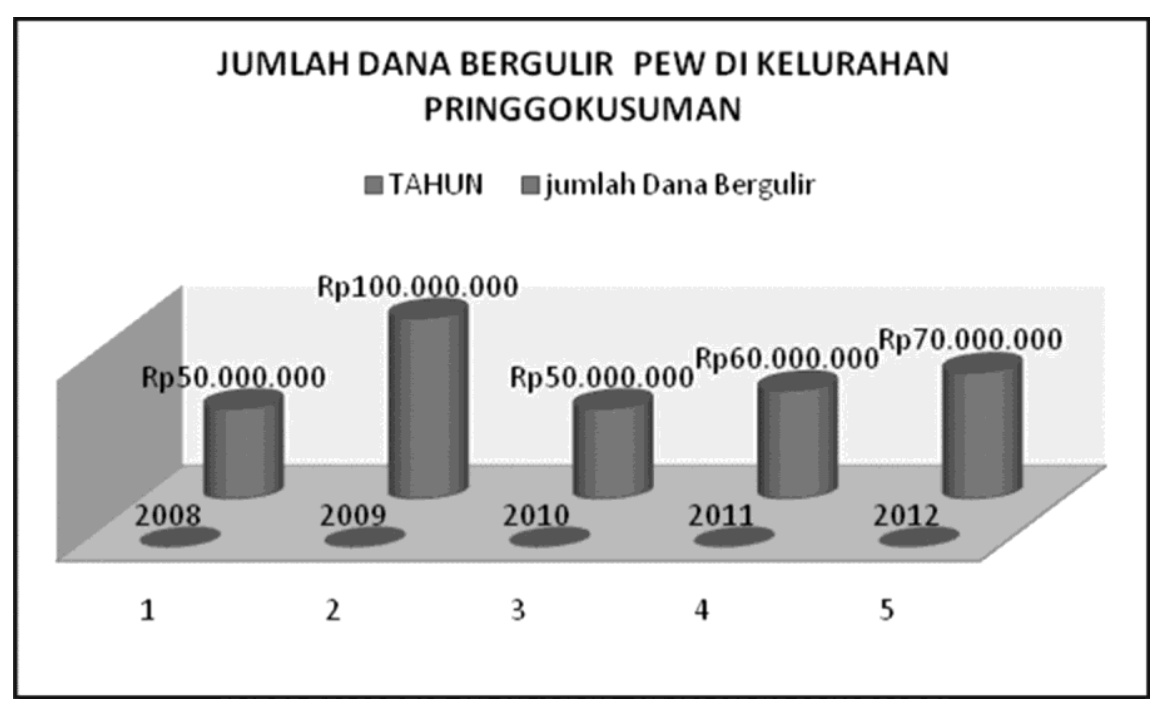

Gambar 3. Jumlah Dana Bergulir PEW di Kelurahan Pringgokusuman

\section{Identifikasi Kapasitas Kelembagaan dan Anggota Kelompok PEW}

\section{a. Aspek Organisasi Kelompok}

Penilaian aspek organisasi yang pertama adalah Jumlah anggota dalam kelompok, dari 33 kelompok penerima bantuan modal PEW di kelurahan pringgokusuman yang memiliki jumlah anggota tiga sampai lima orang berjumlah 4 kelompok atau sekitar $12 \%$, yang beranggotakan 6-10 orang sebanyak 26 kelompok atau sekitar $79 \%$, sedangkan yang beranggotakan 1120 orang sebanyak 3 kelompok atau sekitar 9\%. Hal ini menunjukka bahwa jumlah anggota Kelompok PEW di wilayah Pringgokusuman sebagian besar berkisar antara 6-10.

Tabel 3. Aspek Organisasi kelompok

Aspek Organisasi

\begin{tabular}{|c|c|c|}
\hline Jumlah Anggota & Jml Kelompok & $\%$ \\
\hline a. 3 - 5 orang & 4 & $12 \%$ \\
\hline b. $6-10$ orang & 26 & $79 \%$ \\
\hline \multirow[t]{2}{*}{ c. 11 - 20 orang } & 3 & $9 \%$ \\
\hline & 33 & $100 \%$ \\
\hline \multicolumn{3}{|l|}{ Jumlah Pengurus dalam Kelompok } \\
\hline Jumlah Pengurus & Jml Kelompok & $\%$ \\
\hline a. Min 1 orang & 4 & $12 \%$ \\
\hline b. Min 3 orang ditambah seksi & 29 & $88 \%$ \\
\hline \multirow{2}{*}{ c. Min 3 orang ditambah seksi lengkap } & 0 & $0 \%$ \\
\hline & 33 & $100 \%$ \\
\hline
\end{tabular}


Kehadiran dalam Pertemuan Anggota/ Pengurus

\begin{tabular}{|l|c|c|}
\hline \multicolumn{1}{|c|}{ Tingkat Kehadiran } & Jml Kelompok & $\%$ \\
\hline a. Tidak menentu & 4 & $12 \%$ \\
\hline b. Minimal $75 \%$ & 8 & $24 \%$ \\
\hline c. Minimal $90 \%$ & 21 & $64 \%$ \\
\hline & 33 & $100 \%$ \\
\hline
\end{tabular}

Pertemuan Anggota/ Pengurus

\begin{tabular}{|l|c|c|}
\hline \multicolumn{1}{|c|}{ Pertemuan Anggota/Pengurus } & Jml Kelompok & $\%$ \\
\hline a. Tidak teratur & 8 & $24 \%$ \\
\hline b. Teratur & 0 & $0 \%$ \\
\hline c. Teratur minimal 1 kali/bulan & 25 & $76 \%$ \\
\hline & 33 & $100 \%$ \\
\hline
\end{tabular}

Aturan Main dalam Kelompok

\begin{tabular}{|l|c|c|}
\hline \multicolumn{1}{|c|}{ Aturan Kelompok } & Jml Kelompok & $\%$ \\
\hline a. Ada, belum tertulis & 4 & $12 \%$ \\
\hline b. Ada tertulis, tetapi tidak konsisten & 5 & $21 \%$ \\
\hline c. Ada, tertulis, dilaksanakan & 24 & $73 \%$ \\
\hline & 33 & $100 \%$ \\
\hline
\end{tabular}

Penilaian aspek organisasi yang kedua adalah Jumlah Pengurus dalam Kelompok, dari 33 kelompok penerima bantuan modal PEW di kelurahan Pringgokusuman terdapat empat kelompok yang jumlah pengurusnya hanya satu, ada 29 kelompok (88\%) yang memiliki pengurus minimal tiga orang ditambah seksi, sedangkan kreteria kelompok yang memiliki jumlah pengurus minimal tiga ditambah seksi lengkap tidak ada. Hal ini menunjukkan bahwa sebagian besar kelompok PEW di wilayah Pringgokusuman memiliki kepengurusan yang lengkap ( tiga orang ditambah seksi).

Dari 33 Kelompok PEW di wilayah Pringgokusuman terdapat 4 kelompok (12\%) yang tingkat kehadiran dalam pertemuan kelompok tidak menentu, sedangkan yang tingkat kehadirannya minimal 75\% ada 8 kelompok (24\%), dan yang tingkat kehadirannyan minimal $90 \%$ ada 21 kelompok (64\%). Hal ini menunjukkan bahwa tingkat kehadiran dalam pertemuan kelompok PEW di Kelurahan Pringgokusuman sebagian besar sangat baik.

Dari 33 kelompok PEW di kelurahan Pringgokusuman terdapat 8 kelompok atau sekitar $24 \%$ yang pertemuan anggota/pengurusnya tidak teratur, sedangkan 25 kelompok atau sekitar $76 \%$ yang pertemuan anggota/pengurusnya tertarus minimal satu bulan sekali (gambar 4). 
Hal ini menunjukkan bahwa sebagian besar kelompok PEW di wilayah Pringgokusuman selalu mengadakan pertemuan rutin setiap bulan, hal ini akan menyumbang penilaian dari apek organisasi yang baik untuk masingmasing kelompok PEW.

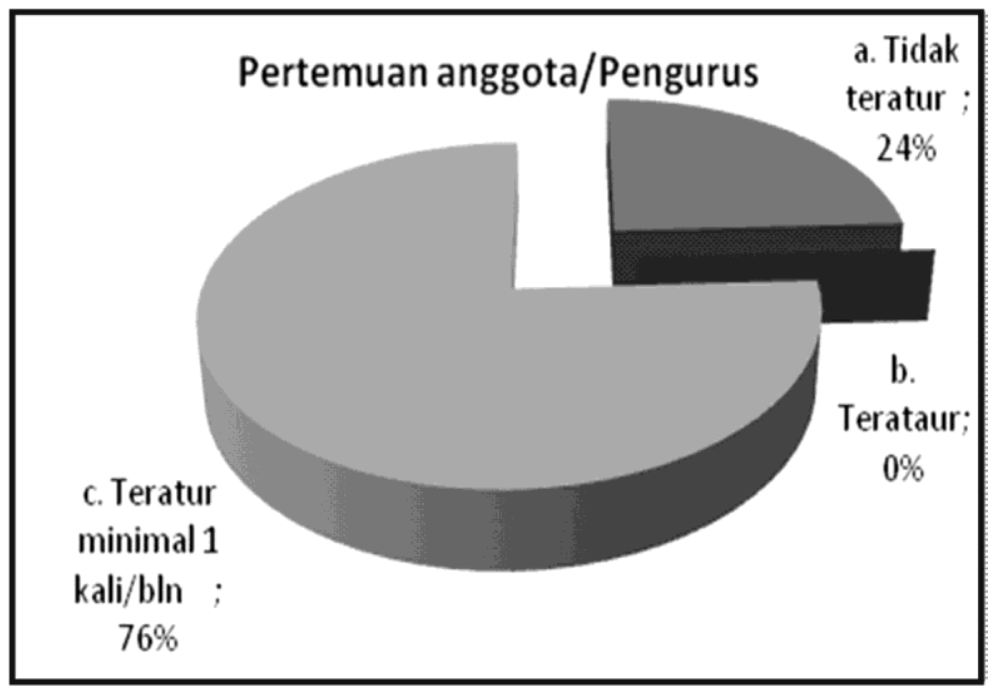

Gambar 4. Pertemuan anggota/Pengurus

Dari 33 kelompok PEW di wilayah Pringgokusuman terdapat empat kelompok (sekitar 11\%) yang sudah memiliki aturan tetapi belum tertulis, dan terdapat 5 kelompok (sekitar 20\%) yang memiliki aturan tertulis tetapi tidak digunakan atau tidak konsisten dalam pelaksanaanya, sisanya 24 kelompok atau sekitar 69\% telah memiliki aturan tertulis dan dilaksanakan dengan baik. Dengan demikian sebagian besar kelompok PEW di wilayah Pringgokusuman telah memiliki aturan tertulis dan dilaksanakan, hal ini menunjukkan hal yang baik ditinjau dari aspek organisasi. Sedangkan untuk kelompok-kelompok yang belum memiliki aturan main dalam kelompok perlu dibina dan didampingi secara intensif oleh fasilitator, sehingga kapasitas kelembagaan kelompok semakin meningkat. Sedangkan kelonpok yang sudah memiliki aturan main kelompok tetapi belum dilaksanakan secara konsisten, perlu dimotivasi agar semua komponen melakukan kontrol internal agar aturan main dalam kelompok bisa dilaksanakan secara konsisten

\section{b. aspek Administrasi}

Dilihat dari aspek administrasi organisasi terdapat sembilan kelompok (27\%) yang sudah memiliki administrasi tetapi belum lengkap, terdapat dua kelompok yang telah memiliki administrasi organisasi yang lengkap tetapi belum digunakan sedangkan sisanya 22 kelompok telah memiliki administarsi organisasi yang lengkap dan telah digunakan. Buku-buku yang diperlukan dalam administrasi organisasi umum ini meliputi : buku 
aturan kelompok, buku daftra pengurus dan anggota, buku daftara hadir pertemuan rutin/kegiatan lain, buku notulen dan buku tamu.

Administrasi Kelompok bermanfaat untuk tersedianya informasi yang komprehensif tentang keadaan kelompok baik yang bersifat umum maupun keuangan bagi anggota maupun pihak luar. Administrasi diperlukan untuk menjaga keakuratan catatan atas semua kegiatan transaksi dan keputusankeputusan yang dibuat kelompok. Manfaat administrasi Kelompok antara lain : sebagai alat kontrol/evaluasi, alat dokumentasi/arsip, sebagai alat/bahan pengambilan keputusan, sebagai alat untuk memonitor perkembangan kelompok, alat pemupuk kepercayaan anggota terhadap pengurus.

Tabel 4. Aspek Administrasi Kelompok

Aspek Administrasi Kelompok

\begin{tabular}{|l|c|c|}
\hline \multicolumn{1}{|c|}{ Administrasi Organisasi } & Jml Kelompok & $\%$ \\
\hline a. Ada, belum lengkap & 9 & $27 \%$ \\
\hline b. Ada, lengkap, belum digunakan & 2 & $9 \%$ \\
\hline c. Ada, lengkap, digunakan & 22 & $67 \%$ \\
\hline & 33 & $100 \%$ \\
\hline
\end{tabular}

\begin{tabular}{|l|c|c|}
\hline \multicolumn{1}{|c|}{ Administrasi Keuangan } & Jml Kelompok & $\%$ \\
\hline a. Ada, belum lengkap & 3 & $9 \%$ \\
\hline b. Ada, lengkap, belum digunakan & 8 & $25 \%$ \\
\hline c. Ada, lengkap, digunakan & 21 & $66 \%$ \\
\hline & 32 & $100 \%$ \\
\hline
\end{tabular}

Sedangkan kreteria yang kedua dari aspek organisasi adalah administrasi Keuangan, Administrasi Keuangan atau pembukuan keuangan adalah catatan transaksi keunagan yang dibuat secara kronologis (menurut urutan waktu) dan sistematis (menurut cara-cara tertentu). Administrasi Keuangan juga dapat diartikan sebagai pencatatan yang berkaitan dengan kekayaan kelompok. Sangat penting untuk mengetahui keadaan kekayaan kelompok dengan jelas/transparan dan sebagai alat untuk pengawasan dalam pengelolaan permodalan kelompok. Sedemikian pentingnya administrasi keunagan ini sehingga dapat dikatakan bahwa nilai administrasi keuangan ini setara dengan nilai uangnya bahkan lebih daripada itu. (Disperindagkoptan kota Yogyakarta, 2012:8).

\section{c. Aspek Permodalan}

Jumlah Kelompok yang memiliki modal swadaya kurang dari 5\% dari modal sendiri berjumlah empat kelompok, sedangkan kelompok yang kriteria modal swadayanya antara 5-9\% dari modal sendiri sebanyak 29 
kelompok atau sekitar $88 \%$. Sedangkan kelompok yang memiliki modal swadaya lebih dari $10 \%$ dari modal sendiri belum ada. Permodalan merupakan variabel penting dalam menilai kinerja kelompok PEW. Semakin besar simpanan anggota maka semakin besar pula Modal sendiri (Equity) yang dimiliki oleh Kelompok. Jika kelompok PEW mengacu kepada sistem koperasi maka ada tiga jenis simpanan yang harus diadakan oleh kelompok PEW, yaitu: simpanan pokok, simpanan wajib dan simpanan sukarela/ Tabungan.

Tebel 5. Aspek Permodalan Kelompok

Aspek Permodalan

\begin{tabular}{|l|c|c|}
\hline \multicolumn{1}{|c|}{ Modal Swadaya } & Jml Kelompok & $\%$ \\
\hline a. $<5 \%$ dari modal sendiri & 4 & $12 \%$ \\
\hline $6.5 \%-9 \%$ dari modal sendiri & 29 & $88 \%$ \\
\hline c. $>10 \%$ dari modal sendiri & 0 & $0 \%$ \\
\hline & 33 & $100 \%$ \\
\hline
\end{tabular}

\begin{tabular}{|l|c|c|}
\hline \multicolumn{1}{|c|}{ Pengembalian Pinjaman } & Jml Kelompok & $\%$ \\
\hline $\begin{array}{l}\text { a. Teratur dengan rata-rata }<75 \% \text { dari } \\
\text { kewajiban }\end{array}$ & 4 & $12 \%$ \\
\hline $\begin{array}{l}\text { b. Terencana dan teratur dengan rata- } \\
\text { rata 75\%-90\% dari kewajiban }\end{array}$ & 11 & $33 \%$ \\
\hline $\begin{array}{l}\text { c. Terencana dan teratur dengan rata- } \\
\text { rata 91\%-100\% dari kewajiban }\end{array}$ & 14 & $42 \%$ \\
\hline d. Macet & 4 & $12 \%$ \\
\hline
\end{tabular}

Sedangkan Jika dilihat dari kriteria pengembalian pinjaman terdapat empat kelompok yang mengalami kemacetan, empat kelompok masuk katagori teratur dengan rata-rata $<75 \%$ dari kewajiban, 11 kelompok termasuk dalam kriteria teratur dan terencana dengan rata-rata 75\% $-90 \%$ dari kewajiban. Sedangkan 14 kelompok termasuk dalam kriteria teratur dan terencana dengan rata-rata 91\% - 100 dari kewajiban.

\section{d. Aspek Usaha Produktif}

Penilaian aspek usaha produktif kelompok PEW terdiri dari manajemen usaha, omzet atau hasil penjualan,pemasaran dan pemantauan usaha seperti terlihat dalam tabel 6 dibawah ini. Dilihat dari manajemen usaha terdapat 13 kelompok belum memiliki rencana pengembangan usaha (sekitar 39\%), sedangkan yang telah memiliki rencana pengembangan usaha sebanyak 11 kelompok (33\%), dan kelompok PEW yang telah memiliki rencana pengembangan usaha dan kelayakan usaha serta dapat menilai 
perkembangannya sebanyak sembilan kelompok atau sekitar $27 \%$.

Sedangkan jika dilihat dari Hasil Penjualan (omzet), ada lima kelompok PEW yang omzetnya masih relatif kecil dan belum berkembang, sedangkan kelompok PEW yang hasil penjualannya mengalami peningkatan sebanyak 16 kelompok atau sekitar 48\%. Kelompok PEW yang SHU atau perolehan labanya mengalami peningkatan sebanyak 11 kelompok.

Tabel 6. Aspek Usaha Produktif Anggota

\section{Aspek Usaha Produktif}

\begin{tabular}{|l|c|c|}
\hline \multicolumn{1}{|c|}{ Manajemen Usaha } & Jml Kelompok & $\%$ \\
\hline a. Blm ada rencana pengembangan usaha & 13 & $39 \%$ \\
\hline $\begin{array}{l}\text { b. Ada rencana pengembangan usaha } \\
\begin{array}{l}\text { c. Ada rencana pengembangan usaha dan } \\
\text { kelayakan usaha serta dapat menilai } \\
\text { perkembangannya }\end{array}\end{array}$ & 11 & $33 \%$ \\
\hline \multicolumn{2}{|c|}{} & $97 \%$ \\
\hline Hasil Penjualan (Omzet) & Jml Kelompok & $100 \%$ \\
\hline a. Masih relatif kecil dan belum berkembang & 6 & $18 \%$ \\
\hline b. Penjualan meningkat & 16 & $45 \%$ \\
\hline c. Rugi/laba meningkat & 11 & $33 \%$ \\
\hline & 33 & $100 \%$
\end{tabular}

\begin{tabular}{|l|c|c|}
\hline \multicolumn{1}{|c|}{ Pemasaran } & Jml Kelompok & $\%$ \\
\hline a. Tradisional/ blm ada jaringan pemasaran & 5 & $15 \%$ \\
\hline b. Pemasaran masih terbatas ditempat lokasi & 10 & $30 \%$ \\
\hline c. Mempunyai jaringan pemasaran & 18 & $55 \%$ \\
\hline & 33 & $100 \%$ \\
\hline
\end{tabular}

\begin{tabular}{|l|c|c|}
\hline \multicolumn{1}{|c|}{ Pemantauan Usaha } & Jml Kelompok & $\%$ \\
\hline a. Usaha Anggota tidak terpantau & 5 & $15 \%$ \\
\hline b. Baru sebagian anggota yg dpt dipantau & 0 & $0 \%$ \\
\hline c. Kelompok memantau usaha anggota & 28 & $85 \%$ \\
\hline & 33 & $100 \%$ \\
\hline
\end{tabular}

Jika dilihat dari Pemasarannya, terdapat lima kelompok yang jaringan pemasarannya massih tradisional atau belum ada jaringan pemasaran sama sekali. Terdapat 10 kelompok PEW di wilayah Pringgokusuman yang pemasarannya masih terbatas di tempat lokasi, sedangkan 18 kelompok PEW atau sekitar 55\% telah memiliki jaringan pemasaran. Dari sisi pemantauan usaha terdapat 5 kelompok yang usaha anggotanya tidak 
terpantau, sedangkan sisanya berjumlah 28 kelompok PEW atau sekitar 89\% merupakan kelompok yang selalu memantau usaha anggotanya.

\section{e. Aspek pengakaran}

Setelah anggota mendapat fasilitas penguatan modal diharapkan usahanya akan berkembang maju. Maka ketika banyak anggota yang usahanya semakin maju stelah bergabung dengan kelompok akan menjadi salah satu indikator bahwa kelompok PEW berhasil. Sehingga hal ini akan memotivasi anggota masyarakat yang lain tertarik ingin menjadi anggota kelompok PEW atau bahkan memotivasi sekelompok masyarakat yang lain untuk membentuk kelompok yang sama.

Tabel 7. Aspek Pengakaran

Aspek Pengakaran

\begin{tabular}{|c|c|c|}
\hline Pengakaran di Masyarakat & Jml Kelompok & $\%$ \\
\hline a. Dikenal & 4 & $12 \%$ \\
\hline b. Dikenal dan diterima & 15 & $45 \%$ \\
\hline \multirow[t]{2}{*}{$\begin{array}{l}\text { c. Anggota Masyarakat banyak yg ingin } \\
\text { masuk }\end{array}$} & 14 & $42 \%$ \\
\hline & 33 & $100 \%$ \\
\hline Jaringan Kerjasama & Jml Kelompok & $\%$ \\
\hline a. Belum ada & 7 & $21 \%$ \\
\hline b. Sudah mulai dirintis & 7 & $21 \%$ \\
\hline \multirow[t]{2}{*}{$\begin{array}{l}\text { c. Sudah ada jaringan kerjasama dengan } \\
\text { pihak lain }\end{array}$} & 19 & $58 \%$ \\
\hline & 33 & $100 \%$ \\
\hline
\end{tabular}

Sedangkan jika dilihat dari jaringan kerjasama, terdapat 7 kelompok yang belum mempunyai jaringan kerjasama, yang telah mulai merintis kerjasama ada 7 kelompok, dan yang sudah mempunyai jaringan kerjasama dengan pihak lain sebanyak 19 kelompok atau sekitar 58\%.

\section{Evaluasi KinerJa Kelompok}

Jika dilihat dari perkembangan Jumlah keanggotaan kelompok terdapat 21 kelompok penerima bantuan PEW yang tidak mengalami penambahan jumlah anggota, diantaranya adalah 5 kelompok yang telah menerima bantuan modal PEW tahun 2008. 


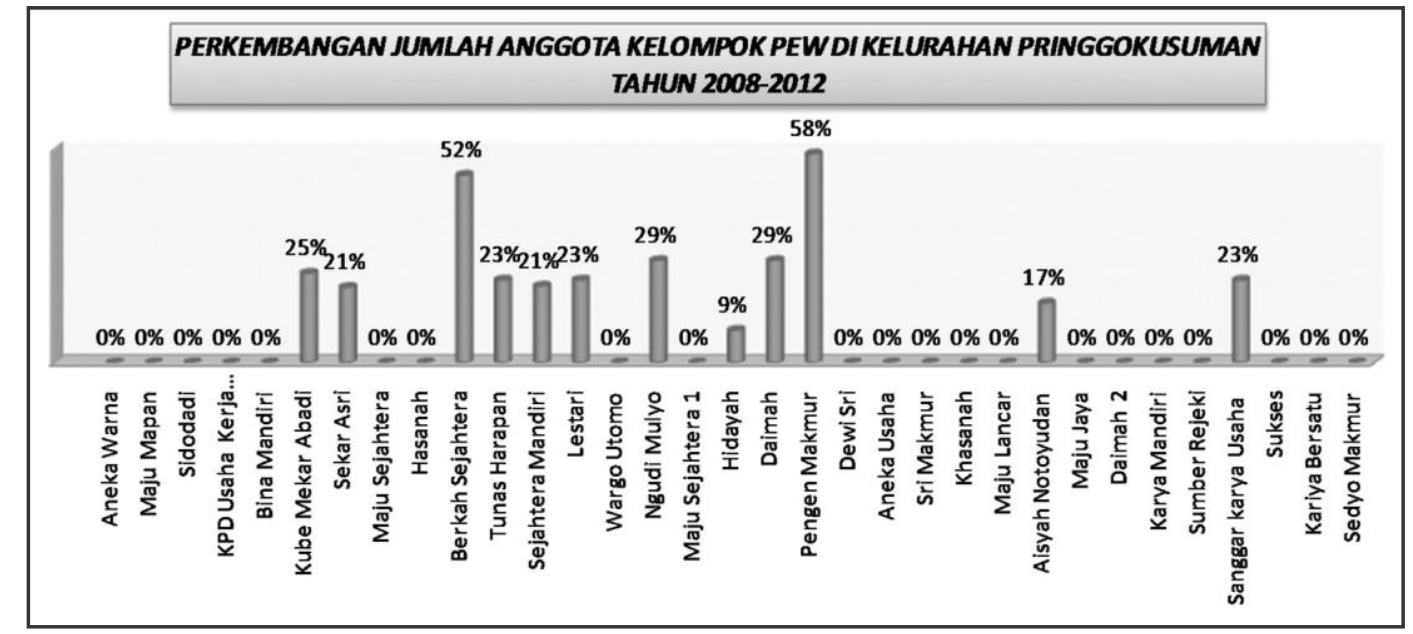

Gambar 5. Perkembangan Jumlah anggota

Perkembangan asset kelompok PEW di Kelurahan Pringgokusuman dapat dilihat dalam gambar dibawah ini. Kelompok Pingin Makmur mengalami perkembangan asset $46 \%$ atau sekitar Rp 8.412.800,00 sejak tahun 2010 , kemudian disusul oleh kelompok sekar asri sebesar $42 \%$ atau sekitar Rp 7.261.683,00 sejak tahun 2009

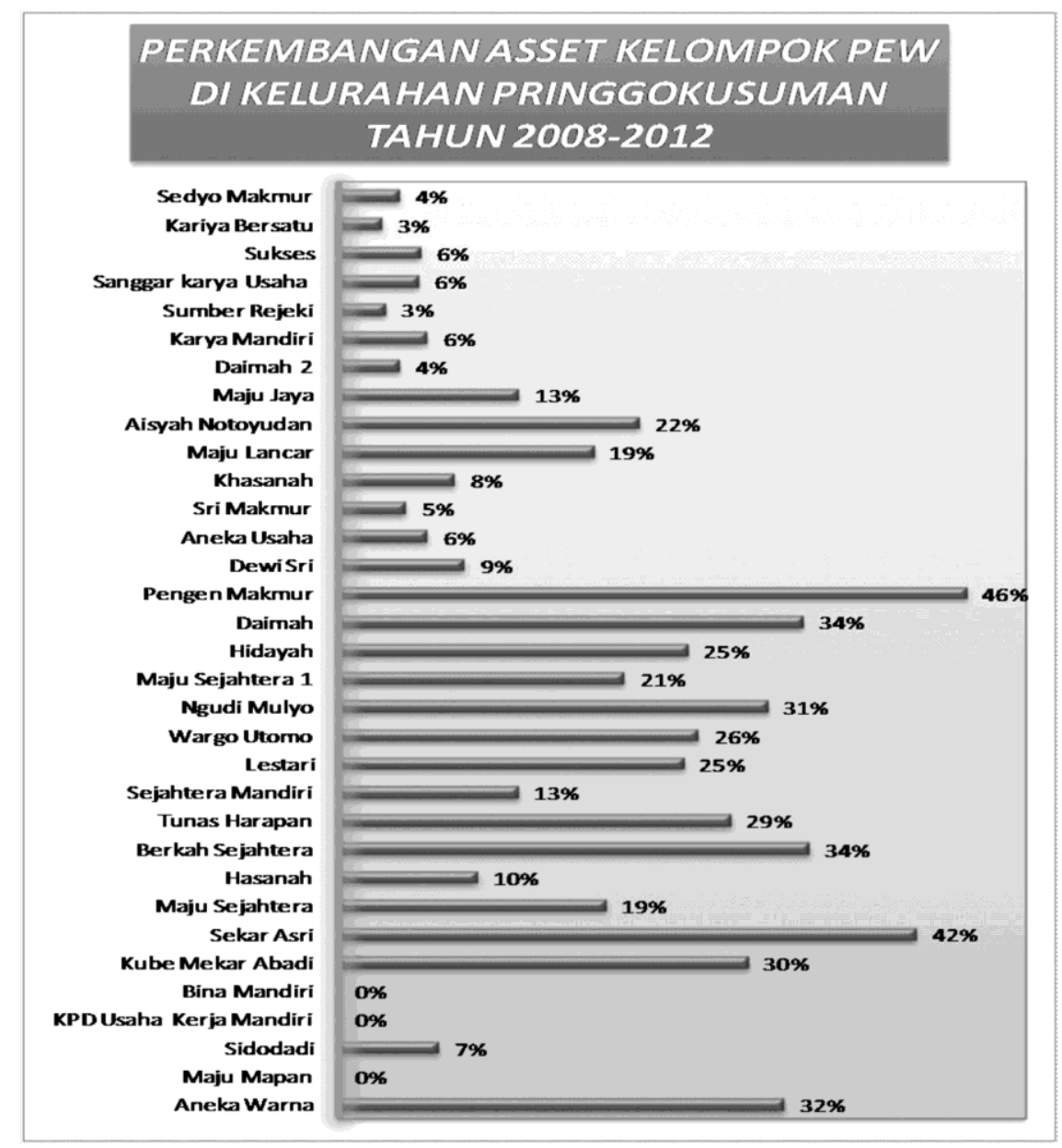

Gambar 6. Perkembangan Asset kelompok 
Hasil yang diperoleh menunjukkan bahwa dari 33 kelompok yang menerima bantuan perguliran modal program PEW dari disperindagkoptan Kota yogyakarta dapat dimanfaatkan oleh anggota kelompok sehingga berpotensi mengembangkan ekonomi lokal. Tingkat pengembalian pinjaman kelompok PEW di Kelurahan Pringgokusuman 76 \% (25 kelompok) tergolong lancar , 12\% tergolong kurang lancar, dan terdapat 4 kelompok (12\%) yang tergolong macet.

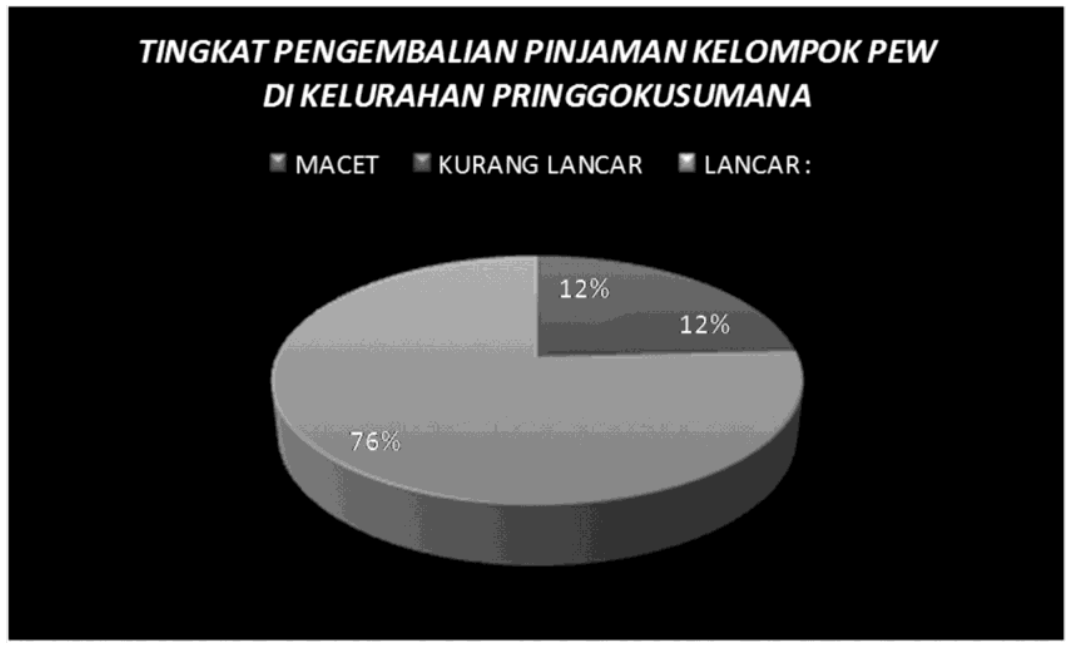

Gambar 7. Tingkat Pengembalian Pinjaman

Dilihat dari arah perkembangan kelompok berdasarkan kinerja aspek organisasi, administrasi, permodalan, usaha produksi dan pengakaran terdapat $18(54,55 \%)$ kelompok yang termasuk dalam kategori pertumbuhan, dan $15(45,45 \%)$ kelompok termasuk dalam kategori pengembangan, sedangkan kelompok yang masuk dalam kategori mandiri belum ada.

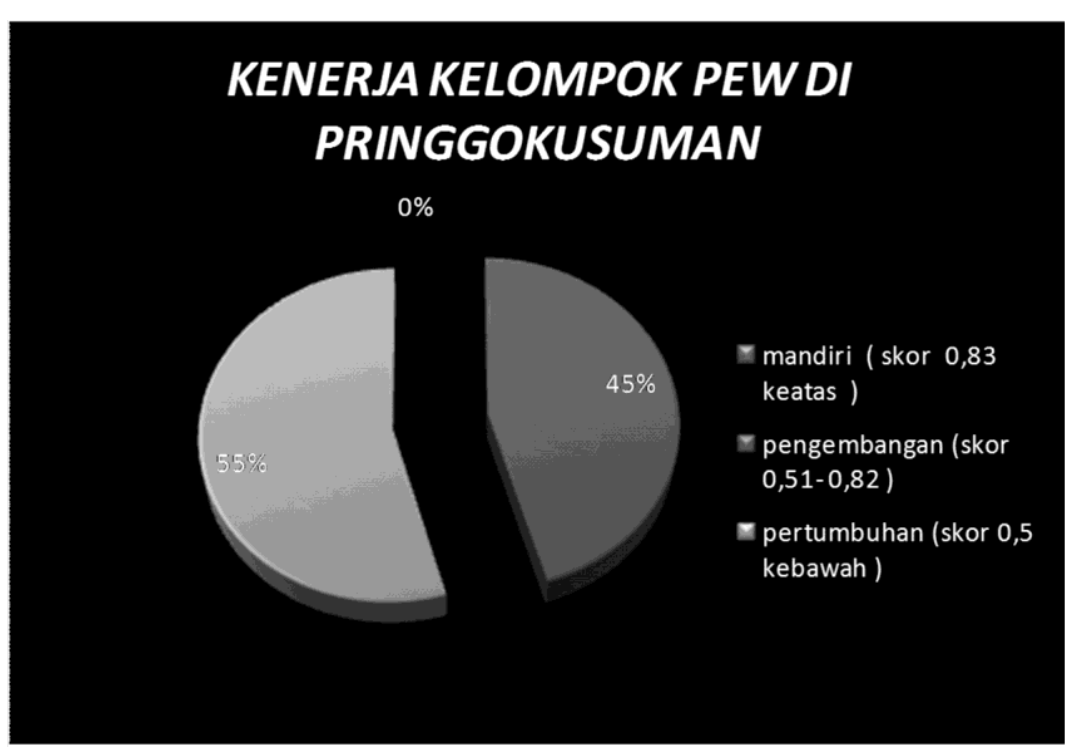

Gambar 8. Kinerja Kelompok PEW 


\section{Rumusan Program penguatan kapasitas}

Rumusan Program penguatan kapasitas kelembagaan kelompok meliputi:

a. Peningkatan Ketrampilan Usaha Ekonomis Produktif Anggota melalalui:

1) Menjalin kerjasama dengan instansi teknis

2) Pelatihan usaha ekonomis produktif bagi anggota dan masyarakat

b. Penguatan Norma Lembaga

1) Mersiapkan bahan sosialisasi

2) Mengadakan sosialisasi kepada masyarakat

3) Mengadakan Pertemuan rutin antar anggota, pengurus dan masyarakat

c. Penataan Administrasi kelompok

1) Menyusun Job Discription

2) Mengadakan pelatihan guna meningkatkan Kemampuan/Kapasitas Pengurus

3) Menyusun Anggaran Dasar dan Anggaran Rumah Tangga Kelompok

4) Melakukan perencanaan kegiatan yang partisipatif

d. Peningkatan Modal Usaha dengan memperluas jaringan kerjasama,

1) Menggalakkan kegiatan menabung

2) Memberlakukan simpanan wajib

3) Menjalin kemitraan dengan lembaga keuangan lain baik formal seperti bank ataupun swasta, BUMN dan instansi pemerintah.

\section{KESIMPULAN}

a. Usaha mikro kecil yang berpotensi di kembangkan di wilayah Kelurahan Pringgokusumana adalah uasaha kerajinan, usaha makanan tradisional, usaha warungan dan niaga. Usaha ekonomi tersebut mampu menopang perekonomian lokal di wilayah Kelurahan Pringgokusuman. Pengembangan usaha ekonomi tersebut perlu mendapatkan dukungan dari pemerintahan setempat dan Dinas terkait dalam hal ini Dinas Perindagkoptan Melalui Program Pemberdayaan Ekonomi Berbasis Kewilayahan

b. Dilihat dari arah perkembangan kelompok berdasarkan kinerja aspek organisasi, administrasi, permodalan, usaha produksi dan pengakaran terdapat 18 (54,55\%) kelompok yang termasuk dalam kategori pertumbuhan, dan 15 (45,45\%) kelompok termasuk dalam kategori pengembangan, sedangkan kelompok yang masuk dalam kategori mandiri belum ada.

c. Kinerja Kelompok PEW di Wilayah Kelurahan Pringgokusuman di 
pengaruhi oleh lemahnya manajemen lembaga yang disebabkan karena rendahnya pengetahuan dan keterampilan pengurus dan anggota dalam pengelolaan usaha; keterbatasan modal yang dimiliki kelompok untuk memenuhi modal usaha anggota; kurangnya partisipasi kelompok dalam perencanaan program, monitoring dan evaluasi pada pengelolaan usaha anggota; kurang adanya kerjasama antara pengurus, anggota, tokoh masyarakat dan instansi terkait. Adapun akibat dari lemahnya manajemen pengelolaan Kelompok PEW tersebut adalah : masih terbatasnya akses permodalan dalam pengelolaan usaha, belum optimalnya usaha ekonomi produktif dalam jejaring pemasaran.

d. Rumusan strategi dan program penguatan kapasitas kelembagaan Kelompok PEW dalam pengembangan ekonomi lokal di wilayah kota Yogyakarta sesuai permasalahan yang telah teridentifikasi, melalui peningkatkan kinerja pengurus dan peningkatkan kesadaran seluruh anggota dalam membenahi manajemen pengelolaan usaha dengan cara :1). Penguatan economic capital, yaitu dengan meningkatkan modal lembaga melalui peningkatan iuran bulanan dan iuran kesejahteraan sosial, disamping mengupayakan usaha peningkatan usaha produktif anggota.2)Penguatan human capital, yaitu mendorong peningkatan pengetahuan dan keterampilan baik bagi pengurus ataupun anggota dalam pengelolaan usaha dan pengembangan lembaga, baik dalam bentuk pelatihan kelembagaan, kewirausahaan dan perencanaan partisipatif, disamping perlunya melakukan studi banding untuk mendapat pengetahuan, keterampilan, teknologi dan informasi pasar atau alternatif permodalan.3) Penguatan social capital, yaitu dengan kesadaran anggota untuk aktif dalam mengikuti pertemuan bulanan yang digunakan sebagai wadah untuk membangun kerekatan dan keterikatan antar seluruh anggota dengan menghasilkan tindakan bersama dan perilaku kerjasama yang diatur dengan norma yang disepakati bersama. Membuka jaringan kerja dan kemitraan dengan lembaga sejenis, untuk memperoleh dukungan, fasilitasi, pendampingan, dengan menjalin komunikasi dengan berbagai sistem sumber untuk mengembangkan lembaga. 


\section{DAFTAR PUSTAKA}

Adi, Isbandi R. 2001. Pemberdayaan, Pengembangan Masyarakat, dan Intervensi Komunitas: Pengantar pada Pemikiran Pendekatan Praktis. Jakarta. Lembaga Penerbit FE-UI.

Cook, James B.1994,.Community Development Theory.Community Development Publication MP568. Dept.of Community Development.University Of Missouri-Columbia.

Dahana, O.P. and O.P Bhatnagar,.1980,.Education and Communication for Development. New Dehli: Oxford \& IBH Publishing CO.

Gunardi, Agung, Sarwititi,S. Dan. Purwaningsih,N,. 2004. Pengantar Pengembangan Masyarakat. MPPM, IPB, Bogor.

Haeruman dan Eriyatno. 2001,.Kemitraan Dalam Pengembangan Ekonomi Lokal. Jakarta, Yayasan Mitra Pembangunan Desa-Kota dan BIC Indonesia.

Hikmat, Harry,.2001.Strategi Pemberdayaan Masyarakat, Humaniora Utama Perss, Bandun.

Ife, Jim. 2002. Community Development: Community Based Alternatives in an Age of Globalizationd, Pearson Education, Australia.

Israel, Arturo, 1992, Pengembangan Kelembagaan. LP3S.,Jakarta

Kartasasmita, G. 1996. Pembangunan Untuk Rakyat Memadukan Pertumbuhan dan Pemerataan .Pustaka Cidesindo,Jakarta

Nasdian \& Utomo, 2004. Pengembangan Kelembagaan dan Modal Sosial. jurusan Ilmu-ilmu Sosial Ekonomi, Fakultas Pertanian, Institut Pertanian Bogor.,Bogor.

Mardikanto,Totok dan Poerwoko.S. Pemberdayaan Masyarakat Dalam Perspektif Kebijakan Publik. Penerbit Alfa Beta, Bandung.

Mikkelsen, Britha, 2003. Metode Penelitian Partisipatoris Dan Upaya-upaya Pemberdayaan. Yayasan Obor Indonesia, Jakarta.

Mulyono, Mauzid. 1993.Penerapan Produktivitas dalam Organisasi. Bumi Aksara ,Jakarta.

Purwadarminta. WJS.1992. Kamus Umum Bahasa Indonesia. Balai Pustaka, Jakarta.

Rubin, Herbert dan Irene S. Rubin,.1992. Community Organizing and Development. Mac Milian Publishing Company, New York.

Subejo dan Supriyanto. 2004. Metodologi Pendekatan Pemberdayaan Masyarakat, short paper pada Kuliah Intensif Pemberdayaan Masyarakat Pedesaan 
Suharto, Edy.2005. Membangun Masyarakat, Memberdayakan Rakyat. Aditama,Bandung.

Suharto, Edy. 2005. Analisis Kebijakan Publik. Alfabeta,Bandung.

Sumarjo dan Saharudin.2004. Metode-metode Partisipatif dalam Pengembangan Masyarakat. Jurusan Ilmu-ilmu Sosial Ekonomi, Fakultas Pertanian IPB, Bogor.

Sumpeno, 2002. Capacity Building, Persiapan dan Perencanaan. Catholic Relief Services, Jakarta.

Sumodiningrat, Gunawan.2003. Pembangunan Daerah dan Pemberdayaan Masyarakat. PT Bina Rena Parawira,Jakarta.

Sutarso. 2005. Praktek Pekerjaan Sosial dalam Pembangunan Masyarakat. BALATBANGSOS DEPSOS RI, Jakata.

Sugiarto,D. 2006. Penguatan kapasitas Lembaga Simpan Pinjam Rukun Lestari untuk pemberdayaan masyarakat miskin, Tesis, Sekolah paskasarjana, IPB, Bogor

Syahyuti.2003. Bedah Konsep Kelembagaan: Strategi Pengembangan dan Penerapannya Dalam Penelitian pertanian. Pusat Penelitian dan Pengembangan Sosial Ekonomi Pertanian, Badan Litbang Pertanian Bogor.

Syaukat, Yusman dan Hendrakusumaatmaja, S.2004. Pengembangan Ekonomi Lokal Berbasis Lokal, MPPM, IPB, Bogor.

Thoha, Miftah.2003 Pembinaan Organisasi, Proses Diagnosa dan Intervensi. PT RajaGrafindo Persada,Jakarta. 